\title{
The morphological structure of complex place names: the case of Dutch
}

\author{
Björn Köhnlein ${ }^{1}$
}

Received: 4 October 2013 / Accepted: 11 March 2014 / Published online: 22 September 2015 (C) The Author(s) 2015. This article is published with open access at Springerlink.com

\begin{abstract}
In the theoretical literature, it is generally assumed that place names are morphologically simplex, at least from a synchronic perspective. This derives from the observation that constituents of complex place names often become opaque over time. Along these lines, place names like Dutch Amsterdam cannot be synchronically compositional because Amster- does not exist as an independent morpheme in Dutch. Contrary to this view, this paper argues that many (Dutch) place names are in fact synchronically complex, in spite of their semantic non-transparency. Evidence comes from the phonological behavior of the names in question: in Dutch, place names are often the sole apparent exceptions to otherwise strong restrictions on stress assignment and phonotactics. Yet under close inspection, it becomes evident that these names are not phonologically exceptional at all: they display regular phonological behavior that is characteristic of morphologically complex words, derived via suffixation or compounding. Furthermore, it is argued that the complex structures found in Dutch place names are by no means idiosyncratic to this group of words: similar patterns are found in place naming in various other languages as well as in the formation of some types of nominal compounds in Dutch (such as the formation of names for ball games).
\end{abstract}

Keywords Place names · Toponyms - Semantic transparency $\cdot$ Semantic opacity · Classifier · Dutch phonology

\section{Björn Köhnlein}

koehnlein.3@osu.edu

1 Department of Linguistics, Ohio State University, 108a Stadium East, 1961 Tuttle Park Place, Columbus, OH 43210-1234, USA 


\section{Introduction}

Proper names are an essential linguistic category. From what we know so far, it seems safe to accept the hypothesis that "all languages have names" (Anderson 2007:169). In everyday life, names occur frequently and, most obviously due to their referential function, play a major role in communication. In language philosophy, the meaning of names has long been a crucial matter, going back to at least Aristotle and Plato. The commonness of names is also reflected in many introductions to linguistics, where sentences in the style of John loves Mary or Sally kisses Frank are prototypical textbook examples to illustrate some of the most basic syntactic relations. In linguistic theory, however, names have been largely neglected so far, despite the fact that they are such obvious language material (with notable exceptions, see, e.g., Longobardi 1994, 2005; Van Langendonck 1998, 2007; Anderson 2004, 2007). One strikingly underinvestigated issue concerns the internal synchronic structure of names: while onomastics has significantly contributed to our understanding of the structural complexity that many names display etymologically, their synchronic morphological structure has not yet received detailed attention. As the original meaning of (at least most) names is opaque to present-day speakers, linguists commonly regard them as being stored non-compositionally in the mental lexicon. Yet, as we shall see, the monomorphemic approach leaves important questions concerning the linguistic behavior of names unanswered.

This paper discusses the relevant issues on the basis of names for settlements (henceforth: place names): on the basis of a case study on place names in Dutch, I argue that many names which scholars have commonly treated as synchronically simplex are rather morphologically complex, in spite of their semantic non-transparency. As shall be discussed in detail, the complexity of such names is also reflected in their phonological behavior.

As a first indication of the morphological complexity that various names seem to display, let us take a brief look at some insights emerging from the onomastic literature on the subject: recurring patterns in the formation of place names, such as compounding and suffixation, have been reported for a variety of languages and language families. To begin with, it is well established that many Germanic place names are etymologically complex and display compound-like structures or show signs of affixation, whether their semantic surface structures are synchronically opaque or not (see, e.g., Dalberg 2008 for Danish; Berkel and Samplonius 2006 for Dutch; Watts and Insley 2004 for English; Bach 1953 for German; among many others). In Germanic, it is usually the ending that marks a word as a name for a settlement. Descriptively, I shall refer to such endings as either toponymic suffixes or classifiers (this follows the common terminology used in onomastics). While toponymic suffixes syllabify with the stem and do not form independent prosodic words, classifiers form prosodic words on their own. The first part of complex place names provides the unique aspects of the name; we can refer to these constituents as referential morphemes. Along these lines, a place name like Dutch Amsterdam consists of a referential morpheme Amster-followed by a classifier -dam; the name Wageningen contains a referential morpheme Wagening- and a toponymic suffix -en. While the occurrence of toponymic suffixes and classifiers is recurring (for instance, there 
are several other place names ending in -dam, as e.g., Rotterdam or Zaandam), that of referential morphemes is essentially non-redundant (only one Dutch place name begins with Amster- orRotter-, respectively). ${ }^{1}$

A particularly clear example indicating the psychological reality of complexity in place naming can be found in the way some place names change over time; consider Danish as an example: Dalberg (2008) demonstrates that over time, the endings of originally simplex place names can take the shape of classifiers that are restricted to the onomastic lexicon; this gives the names a compositional structure. For instance, the endings of several etymologically non-compositional place names changed to -lev over time, as in *Hasli $\rightarrow$ Haslev (Has- + -lev). According to Dalberg (2008:7273), -lev is a name element from the Iron Age without overt 'meaning': its single function is to mark a word as a place name. For German, similar cases are discussed in Nübling et al. (2012:41, and references therein).

Alongside Germanic, complex place names can be found in several other language families: for instance, the Slavic languages Russian and Ukrainian show suffixation processes in forming place names and derivatives, with allomorph selection based on phonological considerations (Phillips 2010). Likewise, in Lithuanian, various settlement names are formed with the suffix -išk, which marks the word as a place name (Endzelyte 2004). For the Finno-Hungarian language Estonian, the basic formula for creating place names has been described as a compound structure consisting of an attributive element and a generic element (Oja and Kallasmaa 2013); yet suffixation is also attested (Päll 2012). For Italian (Romance), Rohlfs (1982) presents a survey of naming strategies for place names. Common patterns are the combination of a classifier followed by an adjective, or the addition of toponymic suffixes to base words, such as personal names. Similarly, Hindi (Indo-Aryan) place names can be formed by attaching the suffix -abad to the name of the founder: the suffix derives from the Persian word abadi 'small settlement'; yet it is synchronically opaque in Hindi and only used to create place names. The same holds for the frequently occurring endings -wada and-gram, which derive from the Sanskrit words for 'village' and 'house' (see Vidal and Gupta 1999 for discussion and further examples).

Bühnen (1992) conducted a comparative study on German and Southern Senegambian place names (Senegal); admitting that his selection of the areas may seem random at first, he points out that "the juxtaposition of place names from two so very different parts of the world leads to significant results. The formation of place names in the two regions follows the same principles [...]" (Bühnen 1992:45). As Bühnen demonstrates, place names in the two languages are usually formed as a combination of a referential and a generic element. Mojapelo (2009) provides evidence that in the Bantu language Northern Sotho, many place names are derived from proper names or common nouns via affixation. For Japanese, Backhouse (1996) reports that the pre-accenting suffix -shi is frequently used as an indicator of city names. In a large-scale study on place naming in Thai (Tai), Prasithrathsint (2007) demonstrates

\footnotetext{
${ }^{1}$ This is not meant to imply that there will never be redundancy in referential morphemes. Similar to homonymity in lexical items (think of, e.g., English bank), there can also be homonymic referential morphemes (as, e.g., in Amstelhoek versus Amstelveen).
} 
that place names in Thai are "normally composed of two main parts: the generic term + the specific name" (Prasithrathsint 2007:63; underlining in original). As a last example, Harvey (1999) reports that some Australian languages use name-specific suffixes to mark place names. Such names are overtly derived from common nouns; yet there are also cases where the initial constituents are synchronically opaque, as attested in Warray (Gunwinyguan); see Harvey (1999:181) for discussion. Harvey (1999:187) also notes that in the languages he discusses, "it is quite common for place names to be compounds, and this is so even in languages such as Gaagudju, where compounding is not otherwise a productive or generally attested process."

In sum, we can conclude that cross-linguistically, place names are often decomposed into two constituents where one constituent marks the word as a place name, and the other contributes a referential element to the word. Crucially, this complexity need not be reflected in a semantic transparency of the constituents. ${ }^{2}$

To gain further insight into issues concerning place naming, this paper presents a case study on the morphological structure of Dutch place names, for the first time systematically incorporating phonological evidence into the discussion. The Dutch language seems particularly suited for such a study as the data are well known and, concerning word stress, phonotactics, and their interaction, it arguably belongs to the most intensively studied languages (see Van der Hulst 1984; Langeweg 1988; Kager 1989; Trommelen and Zonneveld 1989; Visch 1989; Zonneveld 1993; Nouveau 1994; Booij 1995; Van Oostendorp 1995, 1997, 2012; Gussenhoven 2009, among others).

Despite being neglected so far, it seems to me that phonological evidence is particularly relevant for the discussion, as the morphological structure of words is usually reflected in the phonological behavior of the resulting words. The basic reasoning is simple: if Dutch place names were generally simplex, we would expect them to behave like morphologically simplex words; if they were complex, we would expect them to behave like complex words. Indeed, as we shall see on the basis of widely accepted descriptive phonological generalizations on Dutch, many Dutch place names behave in exactly the same way as morphologically complex words. The theoretical literature has always treated them as synchronically simplex and phonologically exceptional (with the partial exception of Zwart 2003; see Section 4 for further discussion); yet phonological evidence suggests that these seemingly exceptional names may not be exceptional at all. I shall argue that they rather constitute morphologically complex forms that participate in regular, predictable patterns of derivation. An analysis along these lines not only gives this large group of words a place in the Dutch grammar, it is also entirely in line with the patterns observed in the brief cross-linguistic survey on related phenomena in other languages. From a more general perspective, the study also establishes a link between theoretical linguistics and onomastics: it demonstrates that etymological knowledge about naming patterns

\footnotetext{
${ }^{2}$ Note that such predictable patterns in names are not restricted to place names. One example for a case of morphologically identifiable suffixation in personal names has recently been put forward in Hermans and Wetzels (2012, fn. 10): Brazilian Portuguese has a productive pattern of forming first names with the suffixes -son and -ton. These endings behave like stress-neutral suffixes: they create stress patterns that violate the stress rules for monomorphemic words. Similarly, names ending in -er have pre-final stress while other words ending in the same sequence have stress on the final syllable.
} 
established in onomastics may still be reflected in the synchronic linguistic structure of names, albeit not overtly.

My argument starts out from the discussion of phonological evidence for structural complexity in Dutch place names, which can be found in phonotactics, stress assignment, and morphological alternations. While, as I hope to show in the course of this paper, the phonological evidence in favor of the approach is straightforward, there are certainly some controversial aspects as well: these concern the morpho-syntactic and semantic status of the relevant morphemes (e.g., Wagening- and -en are both bound morphemes) and the degree of lexicalization the resulting words certainly display. ${ }^{3}$

In a broad sense, I formalize the analysis in a morpheme-based approach to morphology (see, e.g., Halle 1973; Siegel 1974; Kiparsky 1982; Bennis 1993; Lieber 1992; Stonham 1994; Van Oostendorp 2006; Bermúdez-Otero 2012, among many others). Roughly, the proposed semantic / syntactic composition of the relevant constituents is as follows: initial constituents of the complex names in question, such as Wagening- and Amster-, serve a purely referential purpose; that is, they do not carry any semantic features in the traditional sense but contain an invariant 'referential pointer' to a unique object in the world (in the cases at hand: a settlement). The presence of the pointer makes a name a rigid designator along the lines of Kripke (1980). Syntactically, I will classify these referential morphemes as noun stems carrying a feature [+proper].

The corresponding right constituents define the category of the resulting word, as is common for most morphologically complex words in Dutch. With respect to the examples given above, this implies that the morphemes -en and -dam have minimal semantic specifications marking them as place names, respectively; they carry a semantic feature [+settlement]. -en shows the typical phonological behavior of a stress-neutral derivational suffix that syllabifies with the stem. -dam, on the other hand, represents a group of name endings that form prosodic words on their own; when combined with a referential morpheme, this results in a compound. In the formal treatment of the patterns, I will represent morphemes of the compound forming type as noun stems carrying the syntactic feature [+ proper]. To distinguish them from toponymic suffixes, I refer to compound forming morphemes with the term classifier. On the one hand, this term reflects a common notion from the onomastic literature. On the other hand, it serves to indicate a similarity to classifiers found in other languages, which take the shape of nouns but cannot surface independently (see also Section 4).

As this classification suggests, referential morphemes and classifiers are both semantically underspecified noun / name stems: they constitute prosodic words on their own but due to their heavy underspecification, they cannot surface in isolation. That is, only the combination of a referential morpheme (e.g., Wagening-, Amster-) and a morpheme with a minimal semantic specification as a place name (e.g., stress-neutral suffix -en, classifier -dam) leads to a grammatical output form.

\footnotetext{
${ }^{3}$ As the sound string -ingen is common in place names, it may certainly be possible to analyze -ing- as part of a suffix -ingen, rather than treating it as part of the stem; this issue, however, is not essential for my argument (the Dutch data do not provide empirical evidence in favor of one or the other option).
} 
A last tenet in the proposed analysis of complex place names concerns their lexical storage: following a proposal put forward in Bermúdez-Otero (2012), I assume that word-level derivatives can be stored as one lexical entry while retaining their structural complexity; Bermúdez-Otero refers to this type of storage as analytic listing (see also Kaye 1995). A related concept of lexical storage based on psycholinguistic evidence has been proposed in Clahsen and Neubauer (2010, see also references therein). Applying Bermúdez-Otero's model to the (complex) names under discussion implies that speakers will not necessarily have to compute these names 'on line' each time they use them, although they consist of two morphemes; instead, they can be stored in the lexicon as complex units. The grammar has access to these structures, which is reflected in the regular phonological / morphological behavior of these complex forms.

The paper is organized as follows: Section 2 presents the relevant data and discusses seeming violations of well-established generalizations in the phonological system of Dutch. Section 3 contains a morphological analysis of the patterns. Section 4 discusses a previous analysis of complex place names by Zwart (2003). Based on a morphological analysis of names for ball games, I argue in Section 5 that words with comparable structural characteristics to the ones proposed in my analysis can be found outside of place naming. Furthermore, I provide examples showing that in the world's languages, the occurrence of synchronically opaque classifiers is not restricted to place names. Section 6 concludes the paper and briefly discusses issues for future research.

\section{Seemingly irregular stress patterns and phonotactics of Dutch place names}

In Dutch, many place names seem to show irregular stress patterns and phonotactic structures. To begin with, it has repeatedly been noted in the literature that place names like Wageningen, Scheveningen, or Amerongen have highly marked positions of primary stress: these words are stressed on the fourth syllable from the right (e.g., Wá.ge.nin.gen ${ }^{4}$ ), which is not in line with an otherwise practically exceptionless generalization on stress placement in underived words, the so-called Three-Syllable Window. ${ }^{5}$ It is defined in (1):

(1) Three-Syllable Window $(3 \sigma)$ : Primary stress in monomorphemic words is realized on one of the last three syllables of a word.

Along the lines of (1), e.co.no.mie 'economy' (stress on the last syllable), ma.ca.ró.ni 'macaroni' (stress on the penultimate syllable) and ta.rán.tu.la 'tarantula'

\footnotetext{
${ }^{4}$ The string $<\mathrm{ng}>$ in Wageningen represents the dorsal nasal [ $\left.\mathrm{n}\right]$. The dot between $<\mathrm{n}>$ and $<\mathrm{g}>$ in the syllabified form Wá.ge.nin.gen serves to indicate the ambisyllabicity of this consonant.

${ }^{5}$ The only other exceptions are a few grammatical terms of Latin origin (ín.fi.ni.tief, nó.mi.na.tief); note, however, that pronunciation dictionaries also list alternative realizations with final stress (De Coninck 1970; Heemskerk and Zonneveld 2000).
} 
(stress on the antepenultimate syllable) are well-formed monomorphemic words in Dutch; yet the principle prohibits items with preantepenultimate stress (*é.co.no.mie, *má.ca.ro.ni, *tá.ran.tu.la). Place names that do not confirm to $3 \sigma$ are usually regarded as lexical exceptions (see Van der Hulst 1984; Kager 1989; Trommelen and Zonneveld 1989; Booij 1995, among others), which suggests that they should not behave in predictable ways. Yet other words can be derived from these names, and they all have a similar stress pattern: while the place names themselves end in -en, the inhabitant names end in -er, and the names of the local dialects end in $-s$. This is shown in (2):

\begin{tabular}{|c|c|c|}
\hline (2) & Place name, -en & Inhabitant name, -er \\
\hline & Wá.ge.nin.gen & Wá.ge.nin.ger \\
\hline & Sché.ve.nin.gen & Sché.ve.nin.ger \\
\hline & Á.me.ron.gen & Á.me.ron.ger \\
\hline & Hóe.ve.la.ken & Hóe.ve.la.ker \\
\hline
\end{tabular}

\author{
Local dialect, $-s$; attributive, $-s(e)$ \\ Wá.ge.nings(e) \\ Sché.ve.nings(e) \\ Á.me.rongs(e) \\ Hóe.ve.laaks(e)
}

If we regard place names and inhabitant names as non-compositional and thus lexically exceptional, it seems unclear how such predictable alternations should be treated. Furthermore, note that, if morphologically simplex, at least the inhabitant names would incur additional predictable violations of $3 \sigma$. A similar observation can be made with respect to another strong generalization on stress assignment: in monomorphemic words, syllables with a schwa usually directly follow a stressed syllable (Van der Hulst 1984; Kager and Zonneveld 1986; Van Oostendorp 1995, 2000, 2012). The principle is stated in (3):

(3) WeakSchwa: A schwa syllable in an underived word is preceded by a stressed syllable.

In line with WeakSchwa, words like pa.li.sá.d[ə] 'palisade' or mi.rá.k[ə]l 'miracle' are well-formed, as stress is on a syllable that directly precedes a syllable containing schwa; yet the principle prohibits items like *pa.lísa.d[ə] or *mí.ra.k[ə]l, where the schwa syllable would be preceded by an unstressed syllable. Again, the counterexamples are usually place names, such as the ones in (4). Yet these forms show predictable behavior as well - like the place names violating $3 \sigma$, they can be combined with the suffixes $-e r$ and $-s .^{6}$

\footnotetext{
${ }^{6}$ Another piece of evidence in favor of the morphologically complex status of such suffixed names comes from German: the language has an i-initial adjectivizing suffix -isch, and the form Groningisch is attested; notably, the sequence of the dorsal nasal and the high vowel is pronounced as [y]isch, and not as [ $\mathrm{g}$ g] isch. This is of relevance, as the dorsal nasal cannot precede a full vowel in German, with the exception of suffixes starting in /u/ or /i/. In monomorphemic words, the sequence [ $\mathrm{y} \mid]$ is excluded. This is also true for names, as examples like Dschi[yg]is Khan 'Gengis Khan' or the surname of the former tennis player Martina Hi[gg]is indicate. Thus, the phonological make-up of the German word Groningisch indicates that it is a combination of a stem Groning- and a derivational suffix -isch, even though Groning-never occurs as an independent word.
} 
(4)

$\begin{array}{ll}\text { Place name,-en } & \text { Inhabitant name, -er } \\ \text { Bún.scho.t[ə]n } & \text { Bún.scho.t[ə]r } \\ \text { Níj.me.g[ə]n } & \text { Níj.me.g[ə]r } \\ \text { Gró.nin.g[ə]n } & \text { Gró.nin.g[ə]r } \\ \text { Vlís.sin.g[ə]n } & \text { Vlís.sin.g[ə]r }\end{array}$

Local dialect, $-s$; attributive, $-s(e)$ Bún.schoots $([ə])$

Níj.meegs $([ə])$

Gró.nings([ə])

Vlís.sings([ə])

There is another instance where place names violate WeakSchwa: the constraint predicts that there should not be words with two consecutive schwa syllables, as the second schwa syllable would not be preceded by a stressed syllable. In the native vocabulary, this generalization is virtually exceptionless. Yet once more, there are several place names that seem to violate the constraint, and again they display predictable derivational patterns. ${ }^{7}$ Some examples are provided in (5). The derivational patterns are similar to those in (2) and (4), with the exception that these names take the allophone -aar to mark inhabitant names, instead of the allomorph -er (see Section 3 for further discussion).

(5)

$\begin{array}{ll}\text { Me.ch[ə].1[ə]n } & \text { Me.che.laar } \\ \text { Be.m[ə].1[ə]n } & \text { Be.me.laar } \\ \text { Breu.k[ə].1[ə]n, } & \text { Breu.ke.laar } \\ \text { Don.d[ə].r[ə]n } & \text { Don.de.raar }\end{array}$

\author{
Local dialect, $-s ;$ attributive, $-s(e)$ \\ Me.chels $([\ni])$ \\ Be.mels([ə]) \\ Breu.kels $([ə])$ \\ Don.ders([ə])
}

As a next example, let us take a look at the occurrence of superheavy syllables (SH) in place names, i.e., syllables which contain either a diphthong or a tense vowel followed by one consonant, or a lax vowel followed by two consonants (in all cases, one coronal obstruent may follow). SH have two defining characteristics: on the one hand, they are strong stress attractors in Dutch; on the other hand, their occurrence in simplex words is restricted to the final position of a prosodic word (see, e.g., Van der Hulst 1984; Kager 1989; Booij 1995; Van Oostendorp 1995; Gussenhoven 2009). The principles are stated in (6) and (7), respectively:

(6) $S H \rightarrow$ primary stress: A superheavy syllable attracts primary stress.

(7) *SH / non-final: A superheavy syllable is prohibited in non-final position of a prosodic word.

Two prototypical examples of words obeying these restrictions are the nouns do.cu.mént 'document' and ba.náan 'banana', both of which have a stressed final

\footnotetext{
${ }^{7}$ On the surface, such sequences may occasionally arise as the consequence of vowel reduction in adjacent unstressed syllables; this process, however, is highly variable, influenced by a variety of factors (e.g., vowel quality, speech style, frequency, syllable type, etc.), and only applied by some speakers (see Booij 1977; Kager 1989; Van Oostendorp 1995, 2000). As Van Oostendorp (1995, 2000) argues, underlying schwa needs to be treated in a different way from reduced schwa phonologically. The place name Dev[ə]nt[ə]r, however, is a 'true' counterexample to the generalization: it contains two consecutive schwas, yet no signs of morphological complexity; in all derivates, the whole base word is retained (e.g., Dev[ə]nt[ə]raar 'inhabitant name', Dev[ə]nt[ə]rs[ə] 'attributive').
} 
$\mathrm{SH}$. Note that the generalizations are not exceptionless for nouns; yet the number of counterexamples is limited, and they do not show predictable patterns (see Section 3 for further discussion). Once more, however, place names are a rich source of 'systematic exceptions': one of many examples are toponyms ending in the SH -drecht. Such names never receive final stress (as first noted in Schrijnen 1916):

a. Dór.drecht, Slíe.drecht, Pá.pen.drecht, Dúi.ven.drecht

b. Móor.drecht, Zwíjn.drecht, Lóos.drecht, Wíel.drecht

Under a strict monomorphemic analysis, the forms in (8a) violate $\mathrm{SH} \rightarrow$ primary stress, as the only SH in the word is not stressed. The forms in (8b) have an unstressed $\mathrm{SH}$, and are phonotactically ill-formed as well: they also violate $*$ SH / non-final, as their initial syllables are superheavy as well. To this point, all examples given have dealt with cases where stress is realized on a syllable to the left of the expected location - in fact, it was always the word-initial syllable that received stress. Yet there are also cases where stress is systematically realized further to the right than expected in monomorphemic words. For instance, consider place names ending in -dam; as the examples in (9) show, they are stressed on the final syllable (similar to many other place names, such as those ending in -veen or -huizen):

\section{Am.ster.dám, Rot.ter.dám, Schie.dám, Veen.dám, Zaan.dám, E.dám}

Predictable final stress in these forms is exceptional, certainly when these forms are regarded as monomorphemic: only superheavy syllables attract final stress (see above) while other syllable types (heavy and light) avoid stress in word-final position (Van der Hulst 1984, among many others):

(10) NoFinalStress (NFS): Stress is not word-final if the final syllable is not superheavy.

According to (10), có.ma 'coma' is preferred over *co.má, and ró.bot 'robot' is better than *ro.bót. While NFS is not without exceptions in monomorphemic words (there are a variety of French loanwords with final stress, such as ca.déau 'present' or ko.pie 'copy'), the general avoidance of final stress on non-superheavy syllables is reflected in the results of stress assignment tests with nonce words (e.g., Zonneveld 1993; Nouveau 1994; Ernestus and Neijt 2008). Thus, predictable final stress on toponyms ending in the heavy syllable -dam systematically disobeys the principle.

\section{Analysis}

In Section 2, we have seen that when regarded as structurally simplex, many Dutch toponyms violate otherwise well-established phonological generalizations. As I demonstrate below, these problems disappear once we treat the relevant names as morphologically complex synchronically. Under this analysis, the observed patterns are entirely regular and comparable to the behavior of other morphologically complex 
words. In Section 3.1, I demonstrate this for each of the aforementioned generalizations; in Section 3.2, I proceed to the formal representation of morphologically complex place names.

\subsection{Phonological evidence for the morphological complexity of Dutch place names}

\subsubsection{Three-syllable window}

Unlike monomorphemic forms, morphologically complex words are not subject to the $3 \sigma$ generalization; for instance, the word búr.ger.lijk.er 'pettier' is stressed on the fourth syllable from the right. However, as it consists of a disyllabic base word burger 'citizen' followed by the suffixes -lijk (adjectivizing suffix) and -er (comparative suffix), it does not violate $3 \sigma$ (see Booij 1995 for an overview of the phonological behavior of Dutch suffixes).

Consider now the place names that apparently violate $3 \sigma$, as for instance Wageningen. As briefly indicated in Section 1, I argue that this name is not morphologically simplex. Instead, it consists of a referential morpheme Wageningthat can be combined with different suffixes, leading to the forms Wá.ge.nin.gen, Wá.ge.nin.ger, or Wá.ge.ning.s(e), as shown in (2). Crucially, as the base form of the word is only trisyllabic (Wa.ge.ning), $3 \sigma$ is not violated. Notably, the derived forms (inhabitant names, dialects) cannot be derived from a base word Wageningen: e.g., the attributive form of Wageningen is Wa.gen.ing.s[ə], and not Wa.ge.nin.g[ə]n.s[ə].

Looking at these cases only, one may suspect that the -en is not realized for independent reasons, e.g., due to a phonological constraint forbidding two consecutive schwa syllables. Such an analysis, however, would not be borne out by the facts: next to place names like Mech[ə]l[ə] $n$ in (5) that do show two consecutive schwas to begin with, further evidence may be found in place names ending in -hoven (like Eindhoven, Schoonhoven, Tienhoven, Veldhoven, etc). Their derivatives follow the pattern in (11):
Place name, -en
Inhabitant name, -aar
Local dialect, -s; attributive, $-s(e)$ Éind.ho.v[ə]n
Éind.ho.v[ə].naar
Éind.ho.v[ə]ns([ə])

The crucial aspect to note is that the disappearance of -en in Wageninger cannot be the result of a phonological process: this would predict that -en should equally disappear in forms like Eindhovense. As all names ending in -hoven display the same behavior, the pattern can be regarded as regular. The surface difference between attributive forms of the type Wageningse (without -en) vs. Eindhovense (with -en) may reflect that -en has a different morphological status in the two names: while the disappearing -en in Wageningen is a suffix, the retained -en in Eindhovense is part of a morpheme-hoven. Eindhoven should then be regarded as a compound of a name stem 
Eind- and a classifier -hoven. Under this view, it is to be expected that the attributive form surfaces as Eind.ho.v[ə]n.s[ə]: as we shall see below in the discussion on Weakschwa, two consecutive schwa syllables are possible in combinations of a base word and a stress-neutral suffix.

\subsubsection{WeakSchwa}

While being a very strong generalization for simplex words, many suffixed words freely disobey WeakSchwa. Consider the very productive process of diminutive forming in Dutch where the diminutive suffix -tje (or one of its allomorphs) combines with base nouns (see, e.g., Booij 1977; Van Oostendorp 1997; Van der Hulst 2008). Some examples are provided in (12):
a. báby $+\mathrm{tj}[ə] \rightarrow$ bá.by.tj[ə] 'baby-DIM'
b. áuto $+\mathrm{tj}[ə] \rightarrow$ áu.to.tj[ə] 'car-DIM'
c. óv[ə]n $+\mathrm{tj}[\partial] \rightarrow$ ó.v[ə]n.tj[ə] 'oven-DIM'
d. káb[ə]l + tj[ə] $\rightarrow$ ká.b[ə]l.tj[ə] 'cable-DIM'

All four forms end in a schwa that is not preceded by a stressed syllable; (12c) and (12d) additionally contain two consecutive schwa syllables. However, as -tje is a stress-neutral suffix, it is not subject to generalizations on stress placement. Along these lines, we can give a straightforward explanation for the seeming violations of WeakSchwa in the toponyms given in (4) and (5), such as Gró.nin.g[ə]n or Bé.m[ə].l[ə]n. Both names are not monomorphemic but suffixed forms, similar to the type Wageningen, and they can be combined with the same suffixes. The only difference between these forms is the choice of different allomorphs for the demonym suffix, leading to Groninger vs. Bemelaar, which has been motivated phonologically (see Van der Torre 2003; Botma 2004). ${ }^{8}$

\subsubsection{SH $\rightarrow$ primary stress}

Unlike in monomorphemic words, word-final superheavy syllables do not systematically attract stress when they occur in nominal compounds. These are commonly stressed on their first constituent, which is expressed in the Compound Stress Rule (e.g., Visch 1989; Booij 1995):

(13) Compound Stress Rule (CSR): In a nominal compound [[A][B]], [A] carries primary compound stress.

\footnotetext{
${ }^{8}$-er occurs after obstruent-final forms and forms ending in $/ \mathrm{m} /$ and $[\mathrm{y}]<\mathrm{ng}>$, and -aar occurs after all other sonorants.
} 
In accordance with the CSR, the nominal compounds in (14) all have primary stress on the first constituent, and not on the final $\mathrm{SH}$ :
a. [[auto][deur]] áu.to.deur 'car door'
b. [[koffie][huis]] kóffie.huis '(lit.) coffee house, café'
c. [[achter][bank]] ách.ter.bank 'back seat'
d. [[optie][recht]] óp.tie.recht 'option privilege'

As the members of the compounds in (15) form independent prosodic words, $S H$ $\rightarrow$ primary stress is not violated. This in turn explains the seemingly irregular behavior of toponyms ending in -drecht. These items are not exceptional monomorphemic forms, they are regular synchronic compounds:
a. [[Papen][drecht]] Pá.pen.drecht
b. [[Duiven][drecht]] Dúi.ven.drecht
c. [[Slie][drecht]] Slíe.drecht
d. [[Dor][drecht]] Dór.drecht

The number of exceptions to $S H \rightarrow$ primary stress is somewhat greater than for $3 \sigma$ and WeakSchwa. Some counterexamples are provided in (16):
a. fá.kier 'fakir'
b. lí.chaam 'body'
c. ó.li.fant 'elephant'

All of these forms have unstressed final SH, counter to the generalization. It has been argued in Trommelen and Zonneveld (1989) as well as in Booij (1999) that words with irregular superheavy syllables may in fact be prosodic compounds: they are claimed to consist of two prosodic words although there is no detectable morphological complexity (there is some independent morpho-phonological evidence in favor of this claim, which can be found in the above-cited references). When regarded as consisting of two prosodic words, the stress patterns of the names in (15a-d) would be regular, and these forms could be treated as compounds with regular initial stress, according to the CSR. Note, however, that one of the characteristics of alleged prosodic compounds in Dutch is that they do not show regularity in their behavior. That is, there are no specific non-morphemic superheavy syllables that repel stress in the last syllable of a word. Therefore, the forms in (16) are not directly comparable to cases like names ending in -drecht: while the violations of $\mathrm{SH} \rightarrow$ primary stress in (16) are unpredictable and thus truly exceptional, words ending in -drecht always have non-final stress, a regular stress pattern.

As pointed out by a reviewer, the name stem Hóe.ve.laak- itself also violates $S H$ $\rightarrow$ primary stress: it contains an unstressed superheavy final, similar to the nouns in (16). This is a 'true' exception, in the sense that -laak- is not a regular, recurring name ending like-drecht or-dam. Such violations, which can also be found in some other 
name stems (e.g., Nij.meeg-), are not entirely unexpected, however: as shown above, some common nouns disobey the relevant generalization, and there is no reason to assume that underived name stems should be more regular than underived common nouns. Depending on the analytical tool set one choses to use, it would be possible to analyze Hoevelaak- as a prosodic compound or as a monomorphemic word that violates $S H \rightarrow$ primary stress but still satisfies $3 \sigma$, similar to words like ólifant; both options are compatible with my general proposal. Independent of how one treats such stems, it should be noted that in some place names the first, referential morpheme clearly consists of two prosodic words, although this complexity does not contribute to the referential function of the morpheme (e.g., Roe.lof.a.rends.véen; see 3.3 for further discussion).

\subsection{4*SH / non-final}

Unambiguous evidence for the (predictable) compound structure of many place names also comes from the violation profile of $* S H /$ non-final: the constraint prohibits non-final superheavy syllables, yet only in underived words. In compounds, these structures are common, as can be observed in (17):
a. [[huis][deur]]
húis.deur
b. [[tuin][huis]]
túin.huis
c. [[bloed][bank]]
blóed.bank
'(lit.) house door; front door'
d. [[spreek][recht]]
spréek.recht
'garden house'
'blood bank'
'(lit.) speak right; right to speak'

Similar to the compounds in (17), many place names contain superheavy syllables in non-final position, such as the examples in (18). This would be irregular only if these place names were monomorphemic, but it is entirely in line with the grammar once we treat these items as synchronically complex words.
a. [[Moor][drecht]] Móor.drecht
b. [[Zwijn][drecht]] Zwíjn.drecht
c. [[Loos][drecht]] Lóos.drecht
d. [[Wiel][drecht]] Wíel.drecht

\subsubsection{NoFinalStress}

In simplex forms, final stress is generally avoided (with the exception of SH in final position, see above), yet it can regularly arise in some groups of complex words: for instance, it applies to a majority of adjectival compounds (see, e.g., Trommelen and Zonneveld 1986; Backhuys 1989; Visch 1989 for discussion), as indicated in (19a, b). Furthermore, it is the standard stress pattern for copulative nominal compounds (19c, d), and also for combinations of two proper names, such as two place names for one municipality (19e), two given names (19f), or double surnames (19g). As a last example, predictable final stress also occurs in a number of so-called classical compounds, such as words ending in the loan endings -graaf or -gram $(19 \mathrm{~h}, \mathrm{i})$. 
(19)
zwart.wít
'black and white'
b. [[dood][ziek]]
dood.zíek
'seriously ill'
c. [[tolk][vertaler]]
tolk.ver.tá.ler
'interpreter'
d. [[directeur] [geneesheer]]
e. [[Etten][Leur]]
f. [[Jan][Pieter]]
Et.ten-Léur
'head physician'
g.[[Smit][Groot]]
Jan Píe.ter
'Etten-Leur (place name)'
Smit-Gróot
'Jan Pieter (given name)'
h. [[spectro][graaf $]]$
spectro.gráaf
i. $[[$ spectro] $[$ gram $]]$
spectro.grám
'Smit-Groot (double surname)'
'spectrograph'
'spectrogram'

These stress patterns resemble those of place names predictably ending in stressed syllables, such as -dam, as shown in (20). Note that again, some forms contain nonfinal superheavy syllables $(20 \mathrm{c}, \mathrm{d})$, a reliable indicator of structural complexity.
(20) a. [[Amster][dam $]]$
Am.ster.dám
b. [[Schie $][$ dam $]]$
Schie.dám
c. [[Veen][dam]]
Veen.dám
d. [[Zaan][dam]]
Zaan.dám

\subsubsection{Summary of descriptive generalizations}

Table 1 sums up the descriptive generalizations that can be deduced on the basis of phonological evidence from stress assignment and phonotactics. The evidence indicates that the seemingly systematic violations of strong phonological principles in many place names may in fact be no violations at all: rather, these forms show clear characteristics of morphological complexity; they either behave like compounds (type Loosdrecht, Amsterdam, Eindhoven) or like base words combined with stress-neutral suffixes (type Wageningen, Groningen, Bemelen).

Table 1 Descriptive generalizations for Dutch complex place names

\begin{tabular}{|c|c|c|c|}
\hline Place name type & Morphological status & Behavior similar to... & Phonological diagnostics \\
\hline $\begin{array}{l}\text { Wágeningen } \\
\text { Gróningen } \\
\text { Bémmelen }\end{array}$ & $\begin{array}{l}\text { Place name stem }+ \\
\text { stress-neutral suffix }\end{array}$ & $\begin{array}{l}\text { Noun / verb stems }+ \\
\text { stress-neutral suffix }\end{array}$ & $\begin{array}{l}3 \sigma \\
\text { WeakSchwa }\end{array}$ \\
\hline $\begin{array}{l}\text { Dúívendrecht } \\
\text { Lóosdrecht }\end{array}$ & Compound & $\begin{array}{l}\text { Regular nominal } \\
\text { compounds }\end{array}$ & $\begin{array}{l}\text { SH } \rightarrow \text { primary } \\
\text { stress } \\
* S H \text { / non-final }\end{array}$ \\
\hline $\begin{array}{l}\text { Amsterdám } \\
\text { Zaandám }\end{array}$ & Compound & $\begin{array}{l}\text { (Some) adjectival compounds } \\
\text { Copulative compounds } \\
\text { Compounds of two proper names } \\
\text { Classical compounds }\end{array}$ & $\begin{array}{l}\text { NoFinalStress } \\
* S H \text { / non-final }\end{array}$ \\
\hline
\end{tabular}




\subsection{The internal structure of complex place names in Dutch}

In Section 3.1, I have given several examples of place names that seem to disobey strong phonological generalizations on Dutch monomorphemic words; yet it has been argued that these violations are not exceptional but instead display phonological characteristics of polymorphemic words, as in stress-neutral suffixation and compounding. This evidence strongly suggests that the relevant words are morphologically complex, although this complexity does not correspond to overt semantic categories: for instance, both Loos and drecht, which together form the name Loosdrecht, do not occur as independent words in Dutch. Under my approach, both morphemes of complex place names are bound: neither Loos- nor -drecht can occur as independent words, and neither of them has an overt independent meaning.

In general, it is obvious that the etymological meaning of place names is irrelevant for the synchronic 'meaning' of the constituents. On the one hand, the syntactic status of place name classifiers systematically differs from that of the corresponding noun they derive, even in synchronically overt cases like -dam (which derives from dam 'dam'). For instance, while the common noun dam has common gender in Dutch, place names are always neuter and, unlike common nouns, usually appear without a determiner. For its linguistic function as a place name classifier, it is irrelevant whether or not the morpheme corresponds to a lexeme with an overt meaning. This corresponds to the position defended in Mill (1843:21): "proper names are attached to the objects themselves, and are not dependent upon the continuance of any attribute of the object", an approach that has been worked out in more detail by Kripke (1980). The irrelevance of overt meaning in name morphemes seems to be reflected even more clearly in left-hand constituents of place names; it appears to be the case that these referential morphemes can often be entirely 'meaningless', even from an etymological perspective: for instance, in his large-scale onomastic study on German toponyms, Bach (1953) identifies a variety of possible origins of left constituents in place names, be it animal names, names of gods, personal names, etc. According to Bach (1953:352), these constituents often did not contribute any significant meaning to the name but primarily served to distinguish one settlement from another.

The emerging question is whether this lack of overt meaning implies that place names cannot be subject to a morphological analysis at all. As noted in, e.g., Anderson (2007:136), the segmental string -mouth is a recurring element in English place names, even if it does not refer to an actual mouth of a river. Along these lines, one may argue that although Mill's argument is essentially correct (there is not necessarily a correspondence between a place name and the attributes of the corresponding settlement), certain endings of place names can still trigger an interpretation of a specific word as a name for a settlement. That is, I assume that speakers can identify recurring sound strings as place name classifiers / suffixes and store them as independent morphological units. In other words, the repeated occurrence of toponym-endings like -drecht,-dam, or -en, in combination with the accompanying 
phonological characteristics, leads the learner to postulate a corresponding morpheme. Therefore, complex place names like Loosdrecht have a predictable internal structure, consisting of a referential morpheme and a place name classifier. Both units have semantic content, although they are too underspecified to occur as independent words. This differentiates them from 'pseudo-morphemes' in some etymological compounds, as in the Dutch word maarschalk 'marshal': maarschalk historically derives from a compound and still has the corresponding phonotactic structure (e.g. a superheavy non-final syllable), but the original semantic compositionality of the word has been lost entirely (neither maar-nor -schalk are recurring strings that could be identified as meaningful).

Crucially, analyzing such names as compositional is not an argument against the Millian approach - it simply involves a different way of looking at the semantic structure of names: under my view, there can be recurring elements that serve to mark words as place names, although they need not carry any attribute of the settlement itself. One of the reviewers wonders whether this might lead to a paradox, in the sense that we run into a category of words where the morpho-phonology is compositional, but the semantics is not: that is, morphological complexity is used to denote a unique object (for instance, Loosdrecht consists of two morphemes but refers to one settlement). While some kind of mismatch between semantic and morphological structure may be found in other types of common nouns as well (e.g., exocentric compounds, cranberry compounds), this specific relation may indeed be a primary characteristic of names, though not necessarily only of place names. Take for instance lake names, which usually show overt classifiers: for instance, the German word Bodensee '(lit.) Boden Lake, Lake Constance' shows clear signs of morphological compositionality, in the sense that the ending / classifier -see overtly indicates that the whole word refers to a lake, while the constituent Boden- can be regarded as a referential morpheme. The compositionality of the name is also reflected in the Dutch translation Bodenmeer, where the classifier is translated, but the referential morpheme remains unchanged. Thus, the name can be regarded as morphologically complex, although the word denotes exactly one lake. In that sense, lake names and place names are structurally similar; yet while lake names usually show overt classifiers and can be 'felt' to be more compositional, complex place names are intuitively more atomic (since both morphemes are bound). Hence, one possible conclusion might be that the sketched paradox is not linguistic but might rather constitute a mismatch between semantic intuitions (not semantic categories) and morphological categories: that is, since place name classifiers are opaque, the resulting names might be perceived to be simplex; yet, as I have argued, they are in fact morphologically and semantically complex.

Bearing these considerations in mind, let us proceed to the formal representation of complex place names. As briefly addressed in Section 1, I would like to argue that in spite of the structural complexity these names display synchronically, speakers do not necessarily have to compute them on line. Along the lines of BermúdezOtero (2012), I assume that complex words can be stored in the lexicon as a whole, though not necessary as simplex items but as complex units (analytic listing). As the structural complexity of the resulting words is retained, the grammar still has access 
to the individual components (see Bermúdez-Otero 2012, particularly Section 4 for a detailed discussion and different sources of evidence in favor of the general proposal). Under this assumption, the phonology is able to 'see' the internal structure of the names in question, and, accordingly, treats them as morphologically complex forms. ${ }^{9}$ Such complex lexical entries instruct the grammar on how to associate units of representation in different modules; following Jackendoff $(1997,2002)$ and Bermúdez-Otero (2012), I represent these associations by means of coindexation. Consider first the structure of complex lexical entries for suffixed place names on the basis of the example Wageningen, given in (23):

Lexical entry for Wageningen

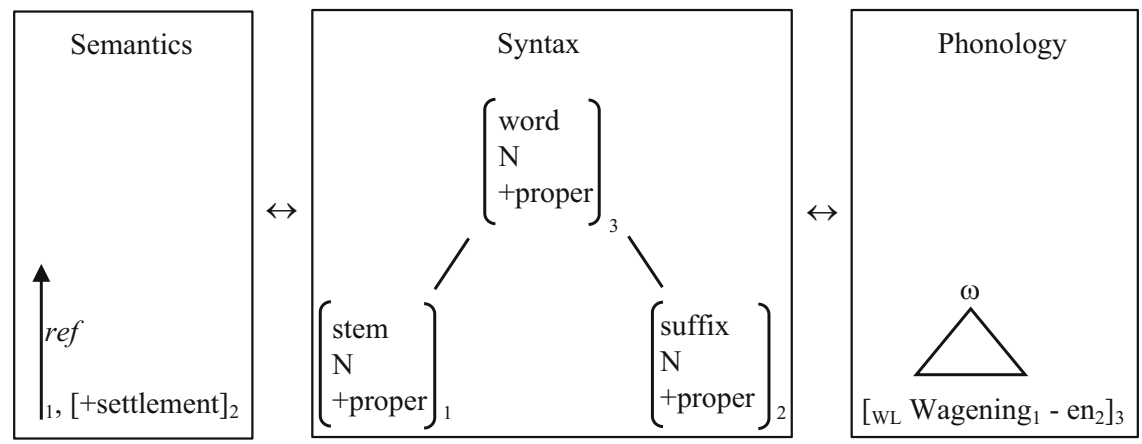

The entry contains a referential morpheme Wagening- (annotated with the subscript 1) and the toponymic suffix -en (subscript 2); the complex word resulting from the combination of these morphemes is annotated with the subscript 3 . The double arrows indicate how the different modules interact: that is, syntax (middle box) and semantics (left box) interact, syntax and phonology (right box) interact, but there is no interaction between semantics and phonology.

I assume that name morphemes always carry a syntactic feature [+proper], which differentiates them from morphemes building common nouns. The phonological string Wagening-, which I have referred to as a referential morpheme throughout this paper, is a noun / name stem whose sole semantic content is a referential pointer (given as ref); the pointer provides a unique reference to a settlement. The morpheme is an independent prosodic word, but it lacks a semantic specification as a settlement. This semantic specification, which I give as the feature [+settlement], is contributed by the toponymic, stress-neutral suffix -en. Due to its stress-neutrality, the suffix does

\footnotetext{
${ }^{9}$ The computation is thus independent of whether a name is analytically listed in the lexicon, or not. This makes it possible to capture regularities in place naming while, at the same time, idiosyncratic aspects can be captured as well; in the case at hand, this particularly concerns the choice of a classifier. That is, there is no inherent linguistic motivation why the name stem Loos- combines with -drecht and not with -dam, or -huizen, etc.
} 
not affect the stress patterns of the underived base word. Therefore, in (23), the suffix is not attached to the prosodic word node at the word level (WL). Instead, we can assume that it will be incorporated in a higher-level node in the prosodic hierarchy. ${ }^{10}$

The representation in (23) also straightforwardly captures the predictable patterns of derivation that these names display. As indicated in (2), the referential morpheme can combine with other suffixes that serve, e.g., a demonymic function (-er), or indicate the local dialect $(-s)$; the derivation follows similar lines. Notably, as -en and -er are stress-neutral suffixes, the resulting forms do not violate the Three-Syllable Window, and are thus phonologically regular.

Let us move on to the representation of names with classifiers, which take the shape of compounds. With respect to these items, we have to distinguish between forms in which the first constituent predictably receives compound stress (type Lóosdrecht) and such where the second member is obligatorily stressed (type Amsterdám). I begin with compound names that have predictable initial stress. Loosdrecht serves as a representative example; its lexical entry is shown in (24): the morpheme Loos- is structurally identical to Wagening-. I represent the classifier -drecht as an underspecified name stem. Like the geographical suffix -en, it provides the semantic feature [+settlement]; the difference between the two types of morphemes is thus of a syntactic rather than of a semantic nature. Being two noun stems, Loos- and -drecht form a compound consisting of two prosodic words; Lóosdrecht then receives compound stress on the initial constituent, in accordance with the CSR (formulated in (13)).

Lexical entry for Loosdrecht

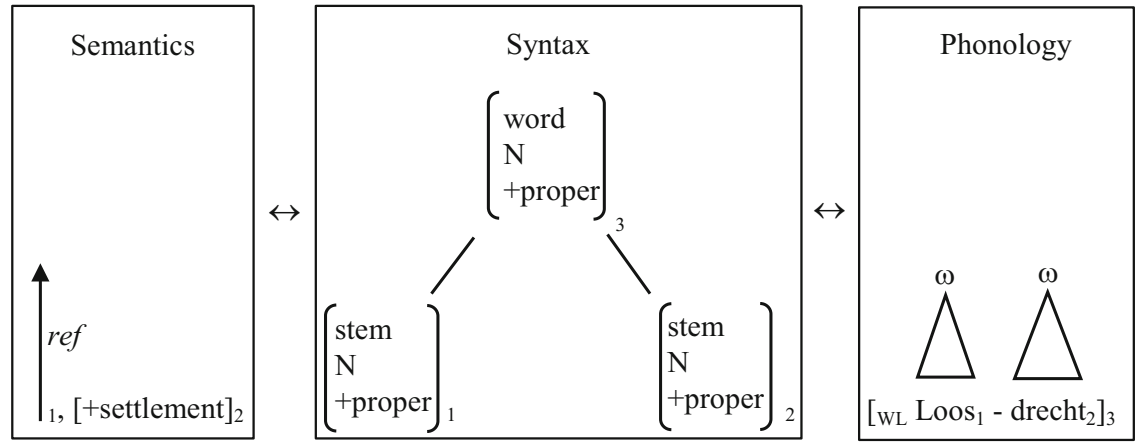

A second category of place name compounds is the type Amsterdám, viz. complex place names with predictable final stress, which is not in accordance with the CSR. Yet recall that predictable final stress is common in other types of words. As shown in (19), it can be found in many adjectival compounds, copulative nominal compounds, complex proper names and so-called classical compounds. To account for

\footnotetext{
${ }^{10}$ There are different proposals as to what this higher-level structure looks like; we could for instance represent this as a recursive prosodic word, but this is not crucial for the argument (see Van der Hulst 2010 for a recent overview of recursion in phonology).
} 
the predictable final stress in the type Amsterdám, I shall assume that classifiers like -dám are lexically marked as stress-attracting. With respect to Dutch, the morphemespecific stress attraction that these classifiers display may best be compared to that of some right constituents in classical compounds, such as -grám. ${ }^{11}$ Such endings share the following characteristics with the place names in question: (i) they cannot occur as independent words, and (ii) they tend to be preceded by meaningful strings that do not exist as independent words, such as spectro-. ${ }^{12}$ The resulting lexical entry for Amsterdam is given in (25); lexical stress on -dám is represented with an acute mark:

Lexical entry for Amsterdam

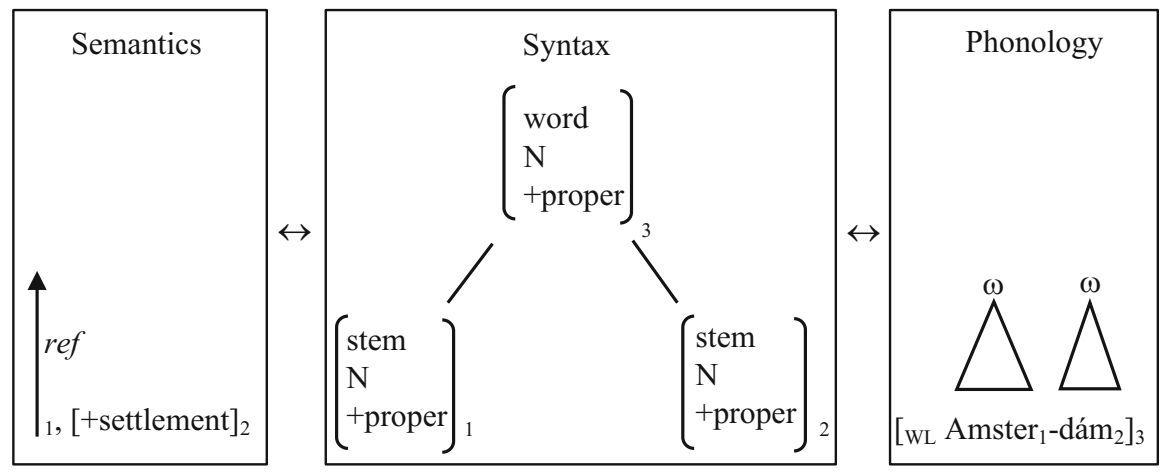

Note that the relevant morphemes can be assumed to have independent lexical entries of their own; yet, as they are heavily underspecified semantically, they will not occur as independent words. Classifiers and geographical suffixes may, however, become relevant for the coining of new / fictive place names. Consider the example of Madùrodám, the name of a Dutch miniature park opened in 1952. The name is composed of two constituents, the surname Madúro and the frequent classifier dám (which is perfectly in line with the analysis sketched above). Interestingly, Madìro- is stressed on the second syllable of the word; such stress patterns do not occur in quatrosyllabic monomorphemic words, which have secondary stress on the first stressable syllable, rather than on the second one (e.g., kàmeleón, *kamèleón 'chameleon'; màrionét, *marìonét 'marionette'). ${ }^{13}$ The stress on the second syllable in Madùro- can thus best be interpreted as an indicator of morphological

\footnotetext{
${ }^{11}$ While according to the CSR, initial stress is the prototypical pattern in nominal compounds, unpredictable stress on second members does occur in Dutch (see, e.g., Van Lessen 1928; Visch 1989; Booij 1995). Thus, there must be a device for marking stress in compounds underlyingly anyway. Also, lexical suffixes, which share semantic similarities with place name classifiers, can also be underlyingly stressed (see, e.g., Leonard 2007 for the Salish language Senćoten).

${ }^{12}$ The final $/ \mathrm{o} /$ in spectro may be a linking element.

${ }^{13}$ It has been claimed, though, that post-initial syllables can carry secondary stress when that syllable is closed or contains a diphthong (Kager 1989). With respect to open syllables with tense vowels (like $d u$ in Ma.du.ro), virtually no potential counterexamples have been reported. Yet, as Booij (1995:fn. 18) notes, the words piraterij 'piracy' and grammatical 'grammatical' can be pronounced with a secondary stress on the second syllable - piràteríj and grammàticáal; according to Booij, the secondary stresses may appear in analogy to the base words piráat 'pirate' and grammática 'grammar'.
} 
complexity. As to why we do not find such post-initial secondary stresses more regularly in Dutch place names, it should be noted that the initial constituents of place names are usually too short to show such stress patterns (they rarely contain more than one stressable, full vowel, as is commonly the case for native lexical morphemes in Dutch). Furthermore, there are various fictional place names that have been coined along the lines of the patterns discussed in this paper, such as Rommeldam (Rommel- + -dám), Stuipendrecht (Stuipen- + -drecht), Nederveen (Neder- + -veen), or Nergenshuizen (Nergens- + -húizen); a collection of these and various other relevant examples can be found in Sanders (2003).

\subsection{Some further considerations}

\subsubsection{Complex first constituents}

It has been argued that the Dutch place names under discussion can be identified as a combination of a name stem (corresponding to one phonological word) plus either a toponymic suffix or a classifier. Yet it should be noted that there are two types of place names that seem to display either more complex or simpler structures on the surface. To begin with, there are some names that display complex first constituents; some examples are provided in (26):

(26) a. Noordwijkerhóut

b. Kootwijkerbróek

c. Roelofarendsvéen

d. Hendrik-Ido-Ámbacht

The names in (26a, b) contain first elements that are overtly derived from other settlement names (Noordwijk, Kootwijk), and these names are used in attributive position, indicated by the suffix -er. Such names might best be analyzed as phrasal; usually, they are stressed on the rightmost constituent (this reflects that default phrasal stress in Dutch is on the right constituent; see Visch 1989).

Of particular interest may be (26c) and (d), as these names show some truly opaque structures. In Roelofarendsvéen, stress on -véen is predictable (place names ending in -veen are always stressed on their right constituent). Crucially, however, the first constituent must consist of two prosodic words synchronically, Roelof- and -arends (etymologically, the first constituent derives from the name of the founder, see Berkel and Samplonius 2006): the name is syllabified as Roe.lof.a.rends.veen, that is, with a syllable boundary between the [f] of Roelof- and the [a] of -arends-. Such a syllabification would not be permitted within a prosodic word, due to a widely acknowledged principle that requires syllables to have an onset while codas are avoided (Onset Maximization, see Kahn 1976); in a monomorphemic word, the syllabification should thus be Roe.lo.fa.rends.veen. The first constituent must therefore consist of two prosodic words. Notably, there is no clear indication that speakers may analyze the first constituent Roelofarends as morphologically complex synchronically, despite the clear evidence that the constituent comprises two prosodic words. Thus, the string Roelofarends may best be regarded as a 'true' prosodic compound 
in the sense of Trommelen and Zonneveld (1989) and Booij (1999); it is phonologically complex but corresponds to one referential morpheme. Another unusual name is Hendrik-Ido-Ambacht, which arguably combines a non-redundant complex first constituent Hen.drik.I.do, historically derived from a personal name (van Berkel and Samplonius 2006), with a unique classifier ambacht '(lit.) craft'. Again, the syllable break between the $<\mathrm{k}>$ of Hendrik and the $<\mathrm{I}>$ of Ido clearly indicates a boundary between two prosodic words.

\subsubsection{Place names without overt marking}

Going the opposite direction in terms of overt complexity, we also find arguably simplex names like Delft, Baarn, or Olst. There seem to be two ways to analyze these names: they may either be regarded as truly monomorphemic - in this case, they would combine a referential pointer and a semantic specification [+settlement] in one morpheme. Alternatively, one could regard a name like Delft as a combination of a referential morpheme followed by a zero morpheme that provides the lexical semantic specification. On empirical grounds, I do not see sufficient evidence to prefer either of the options. Yet, as suggested to me by M. van Oostendorp, the analysis with a zero suffix may be in line with another phenomenon in Dutch: some compound names for Dutch museums can be used with or without their second constituent; e.g., it is possible to refer to Het Stedelijk Museum '(lit.) The Municipal Museum' as either Het Stedelijk Museum or just Het Stedelijk, without the category-providing noun museum. Thus, it seems that in such cases, the categoryproviding noun can remain unexpressed on the surface, though it is still present as a zero morpheme. Similar structures could then be assumed for overtly simplex place names like Delft with the difference that the second constituent would never be expressed. The reason that we do not find optional deletion of the classifier in names like Amsterdam may be related to the fact that unlike in the museum case, name classifiers are not semantically overt and may therefore not be subject to deletion.

Further evidence for zero classifiers in naming comes from German, where names for various groups of objects have fixed articles: for instance, car names are always masculine, and ship names are always feminine (e.g., die Alexander von Humboldt 'the.FEM', named after Alexander von Humboldt). Such structures have been analyzed as headless noun phrases (Köpke and Zubin 2005), but along the lines of the approach suggested here, they might also be regarded as combinations of a referential morpheme and a zero morpheme contributing the article. I will leave a more detailed discussion of such cases to further research.

\subsubsection{Variation in stress placement}

There are some name endings that can either appear as stressed or unstressed synchronically; most prominently, this is the case for the frequent name endings -wijk, -dijk, and -stein, as can be exemplified by the oppositions between Wáalwijk vs. Winterswijk, Moerdíjk vs. Áchterdijk, or Zwéinstein vs. Ravenstéin; the words can 
be analyzed with the available tools as having separate classifier morphemes, either marked or not marked for stress.

\subsubsection{The classifier -hem}

As a last issue, I would like to briefly address the status of the classifier -hem, which we find in place names such as Arnhem, Honthem, Nunhem, Oosthem, etc. The morpheme can be pronounced in two ways, in a non-reduced version [hem] as well as in the reduced form [əm]. The former is comparable to other classifiers that constitute independent prosodic words while the reduced form has a more monomorphemic character: the full vowel reduces to schwa, and /h/ deletes accordingly; in Dutch, $/ \mathrm{h} /$ is prohibited before schwa ([*hə]; see Booij 1995). It thus seems to be the case that place names ending in -hem have two alternative realizations, one as a compound with a classifier versus one in which the names are realized as one prosodic word.

\subsubsection{Names with final stress as synchronic phrases}

A reviewer points out that place names ending in -dam might alternatively be analyzed as syntactically complex. This is in line with the etymology of the place name Amsterdam, which arguably derives from a possessive phrase, analogous to the place names in $(26 \mathrm{a}, \mathrm{b})$. This is a viable option, particularly for the name Amsterdam (and Rotterdam as well), where the -er ending of the first constituent could indeed be interpreted as a (possessive) suffix. Yet the analysis is less straightforward for related place names such as Schiedám or Veendám. In these names, the first constituent does not have a suffix (*Schieerdám, *Veenerdám), but the stress pattern is the same as in Amsterdám. To include names like Schiedam and Veendam in the analysis, one would arguably have to stipulate that in phrasal names, the first, referential constituent may or may not show overt suffixation. One might add that, following van Berkel and Samplonius (2006), neither of the names has a phrasal origin - thus, the stress patterns cannot be derived from the etymological structure of these place names.

\section{A previous account: Zwart (2003)}

While Dutch place names have commonly been treated as morphologically simplex in the literature, Zwart (2003) has argued that some place names are in fact complex: he claims that place names of the type Loosdrecht (initial stress) are morphologically simplex and have preserved a Germanic accentuation pattern with initial stress (Zwart 2003: 400). Place names of the Amsterdam type (final stress), however, are regarded as synchronic compounds. Stress on the second constituent can be derived from the syntactic structure of these items, which equals that of copulative compounds (see 19c, d) and combined names (see 19 e, f). 
Zwart's contribution contains many valuable insights about the internal structure of compounds and can successfully derive the relevant patterns; yet some issues still remain. Most evidently, although there are structural differences among different place names, the resulting stress patterns still seem to be properties of individual items, rather than generalizations across groups of words. That is, Zwart does not provide an underlying representation from which it would follow that place names of the type -dam always receive final stress, and names of the type -drecht are never stressed on their final syllable. Also, the segmental structure of an arguably simplex name like Loosdrecht is certainly not that of a typical Germanic simplex word - as discussed in Section 2, superheavy non-final syllables are highly marked in Germanic. Thus, under Zwart's approach, the stress system and the phonotactics of monomorphemic place names would be fundamentally different from the patterns found for other major parts of speech (it should be noted, however, that Zwart's paper primarily focuses on family names and does not explicitly aim to present a full-fledged analysis of place names).

Notably, there may also be empirical evidence indicating that words of the type Amsterdám and combined names like Etten-Léur have different internal structures, unlike what would be expected under Zwart's account. ${ }^{14}$ It has been noted in the literature that place names like Amsterdam can be subject to a process referred to as stress retraction (see Gussenhoven 1984; Visch 1989; Booij 1995): when used in attributive function, primary stress in Amsterdam regularly shifts from the last syllable to the first one, as shown in (27a); bos 'forest' carries phrasal stress. ${ }^{15}$ Yet no such stress shift takes place in Etten-Léur (27b). This indicates that the internal structures of these name types differ from each other. Furthermore, classical compounds show stress shift as well, as illustrated in (27c). This supports the idea that complex names with predictable stress on the second constituent share a comparable structure with classical compounds showing final stress.
a. het Ámsterdamse bos
'the Amsterdam forest'
b. het Etten-Léurse bos
'The Etten-Leur forest'
c. een spéctrografische analyse
'a spectrographic analysis'

I argue that my analysis can capture the different stress patterns of names like Etten-Leur, Loosdrecht, and Amsterdam in a representational way. Etten-Leur is a compound of two names where each contains a referential pointer (final stress, no stress shift). Loosdrecht is an unmarked place name compound with compound stress on the first constituent. Amsterdam, then, is a compound name with a right

\footnotetext{
${ }^{14}$ In his paper, Zwart does not use combined place names as examples but combined family names; yet structurally, these two types should be identical.

${ }^{15}$ The examples also indicate that, when inhabitant names are formed from place names with a classifier, the classifier is retained, unlike what we find for suffixed names like Groningen vs. Groninger, where -en deletes. It seems to be the case that place name classifiers, being underspecified noun stems, are morphologically 'stronger' than corresponding suffixes, which results in the necessity to realize them on the surface.
} 
constituent underlyingly marked for stress (final stress, stress shift). Particularly the distinction between Amsterdam and Etten-Leur cannot be made under Zwart's approach. Furthermore, my account avoids the necessity to postulate a co-phonology for names, which Zwart would need to do in order to derive the Germanic stress pattern.

It should be noted, however, that Zwart provides some independent evidence in favor of the Germanic stress pattern: in Dutch, surnames derived from place names with stress on the final constituent often show a stress shift from the right constituent to the first one (as described in Kaufmann 1977; Van den Toorn 1980). Zwart provides the example Moerdijk, where the place name has primary stress on -dijk (Moerdíjk) but the corresponding family name on Móer- (Móerdijk). As Zwart demonstrates, the shift also occurs when original noun phrases are used as surnames (Huis in het véld '(lit.) house in the field' > Húisinhetveld); yet shifts do not occur in "exotic family names such as pastóor, tabák" (Zwart 2003:396), which exhibit the same stress pattern as the corresponding nouns pastóor 'priest' and tabák 'tobacco'.

Following Zwart, I assume that the surnames displaying stress shift are 'more atomic' than corresponding place names; yet, while Zwart's solution suggests a cophonology for names to derive the relevant stress patterns, I would like to tentatively suggest that the difference may in fact be representational: as I have argued in this paper, many place names are composed of a referential morpheme and a place name classifier. This distinction may not be valid in the same way for surnames: assuming that a place name classifier cannot function as a surname classifier, -dijk would therefore lose its status as a place name classifier. Thus, it may well be the case that it also loses the representational characteristics accompanying this status, i.e., its stress attraction. This would explain why stress shifts leftwards in the transition from the place name Moerdijk to the family name Mórdijk.

A comparable analysis may be possible for place names like Húisinhetveld. Such names may lose their phrasal status, as such phrasal structures would be ungrammatical family names. As a consequence, phrasal stress would also be lost, and what remains would be a lexicalized prosodic compound of the structure [[huis][in][het][veld]], with initial stress due to the CSR. ${ }^{16}$

Further evidence that the stress shift may be structurally conditioned, rather than deriving from a special phonology of 'Germanic' names, comes from some types of arguably simplex native / nativized place names with non-initial stress. Consider the examples in (28):
a. Bredá > van Bredá
b. Parijs 'Paris' > van Paríjs

\footnotetext{
${ }^{16}$ One problematic set of data for such an analysis is mentioned in Zwart's paper: there are a few Dutch family names that display phrasal structures on the surface, such as Olde Dáalhuis. Such infrequent and unusual names do not easily fit in with a theory predicting that phrasal structures should be transformed to (prosodic) compounds. Aside from this issue, there are various other patterns in family names worth discussing in more detail. As such a discussion is outside the scope of this paper, I will leave these issues for further research.
} 
Presumably, when turned into family names, these place names do not undergo stress shift as they do not show any overt signs of morphological complexity, and can be assumed to consist of one prosodic word. Accordingly, their stress patterns are not morphologically conditioned. Therefore, Bredá (28a) has exceptional, lexicalized word stress on the final syllable, and the nativized name Parijs (28b) contains a final superheavy syllable, resulting in phonologically regular final stress. These data are problematic for a Germanic stress approach but are perfectly in line with my analysis.

\section{The relation of morphologically complex place names to other types of complex words}

The analysis of place names, as developed in Section 3, largely relies on one basic claim concerning the internal structure of morphologically complex place names in Dutch, viz. that they consist of two bound morphemes. While at first sight, such a combination of morphemes may seem unusual, it may be far less unusual than one may suspect. To exemplify this, consider the formation of Dutch compound names for ball games with the morpheme - bal '(lit.) ball' as a second, category-defining constituent (similar structures can, of course, be found in other Germanic languages). The structure of these names follows predictable patterns: let us begin with the Dutch word voetbal 'football, soccer', which is commonly regarded as a regular nominal compound (see Trommelen and Zonneveld 1989:82; Booij 2007:79). Crucially, however, neither of the two constituents voet-and -bal can surface independently, at least not without losing the meaning they contribute to the compound. In voetbal, the right constituent - bal provides a semantic category; it indicates that the word denotes a ball game. Yet bal cannot surface on its own with the meaning 'ball game' - it is grammatical to say Ik hou van voetbal 'I love football', but *Ik hou van bal 'I love ball' is ungrammatical. Thus, its behavior is comparable to the right constituents of the complex place names discussed in this paper, such as -drecht; it functions as a bound classifier for ball games. The left constituent voet- '(lit.) foot' contributes far more than only indicating that the game is primarily played with feet (but various other body parts can be used to touch the ball as well); it captures the rules and various other aspects of the game. ${ }^{17}$ Crucially, this specific meaning can only be expressed when the morpheme is combined with bal. In that sense, voet- is a unique morpheme, similar to the initial constituents of place names, as for instance Loos-in Loosdrecht.

While one may argue that in voetbal, the meaning of the first constituent is still overt to a certain degree, there are other ball games where the first constituent can

\footnotetext{
${ }^{17} \mathrm{~A}$ reviewer notes that voetbal is probably a loan translation from English, but I do not think that this aspect has an effect on the synchronic status of the word for present-day speakers. Another reviewer argues that voetbal may not be a compound anymore but synchronically deverbal, deriving from the Dutch verb voetballen '(lit.) to football, to play football'. This analysis may be possible for Dutch (although I would not necessarily want to commit to it); yet it wouldn't work for related languages like English or German. Here, verbs such as *to football or *fußballen are unattested, but the formation of ball games is the same as in Dutch. The analysis proposed in this paper can derive the patterns in all three languages from the same principle; therefore, it seems preferable over the deverbal approach, which would be limited to Dutch.
} 
be safely assumed to be entirely opaque to most speakers. As examples, consider the rather unknown ball games smolball and rafroball: in both cases, the first constituents derive from parts of the inventors' names but do not exist as independent words. ${ }^{18}$ Instead, they exclusively serve to indicate a specific ball game, which again shows clear similarities with initial constituents in place names.

To sum up, in words for ball games as well as in the place name compounds discussed in this paper, the right constituents indicate a semantic category for the whole word, and the initial constituents provide the unique aspects of the name. Crucially, none of these morphemes can appear on their own with their specific meaning - thus, what names for places and for ball games have in common is that they consist of two bound morphemes, and they 'need' each other to form a grammatical item. In other words, the proposed structure for place names is by no means restricted to the formation of place names.

Outside of Dutch, synchronically opaque morphemes displaying the characteristics of lexical morphemes are cross-linguistically well attested: for instance, the term lexical suffix has been used to refer to bound morphemes "with lexical rather than grammatical functions", as defined by Kinkade (1963:352). Such suffixes are very common in Salish languages and used productively (see, e.g., Thompson 1974; Gerdts 2003). Historically derived from nouns, the relevant morphemes can only occur at the right edge of compounds, similar to place name classifiers. Furthermore, Aikhenvald (2000:442-446) summarizes data from various languages where (originally) free morphemes are used as classifiers with various functions; these classifiers are often synchronically opaque, similar to those found in Dutch place names. ${ }^{19}$ Furthermore, Mandarin Chinese contains a set of bound morphemes that only occur in compounds. These bound morphemes (which take the shape of nouns) can be freely combined with other free morphemes, or with bound morphemes. That is, there can be compounds consisting exclusively of bound morphemes (Sproat and Chilin 1996; Packard 1998). This may serve as yet another indication that semantically underspecified lexical morphemes are not uncommon in the world's languages.

To end this section, let me briefly discuss the relation between the referential morphemes and so-called 'cranberry morphemes' (e.g., Aronoff 1976), i.e., morphemes whose occurrence is restricted to one lexical item (such as cran- in cranberry). At least for the sake of comparison, let us assume that cranberry morphemes are independent morphemes. Under this view, cranberry morphemes certainly share similarities with referential morphemes: both units form their own prosodic word but are semantically underspecified; therefore, they cannot surface independently. Yet at the same time, these two types of morphemes are quite different in their referential function: as I have argued, referential morphemes denote unique objects in the world; consequently, they always appear in the singular. Cranberry morphemes, on the other

\footnotetext{
${ }^{18} \mathrm{Smol}$ - consists of the first four letters of the surname Smolinski. Rafro-, incorporates parts of the surnames Rapillard and Frossard.

${ }^{19}$ Yet cf. Booij (2010:71-73) who argues that such patterns provide evidence in favor of construction morphology.
} 
hand, refer to classes of objects. Thus, unlike a referential morpheme, a cranberry morpheme cannot contain a referential pointer to a unique object; this would make the wrong prediction that there is only one cranberry in the world. Instead, it must carry some specific semantic information which identifies it as some kind of berry, yet without carrying a feature like [+berry] itself - under this view, cran- cannot surface independently but only in combination with the 'overt classifier' berry. In that sense, cran- in cranberry shares more similarities with voet- in voetbal than with Loos- in Loosdrecht, although all three types of words are certainly related.

\section{Summary and conclusion}

In this paper, I have proposed a morphological analysis of complex place names in Dutch. It has been shown that when analyzed as morphologically complex, many place names that are usually regarded as phonologically exceptional can be shown to display predictable linguistic behavior. It has been found that many place names in Dutch, as in many other languages, consist of two bound morphemes, a referential morpheme and either a classifier or a toponymic suffix. I have argued that the combination of semantically underspecified morphemes is not restricted to names: for instance, similar strategies can be found in the formation of names for ball games. Furthermore, morphemes comparable to place name classifiers are attested in various other languages.

To conclude, I believe that the proposed analysis opens a wide range of possibilities for further research: synchronic morpho-phonological studies on place names and other types of names are virtually absent in the literature on Dutch as well as other languages. The cross-linguistically comparable general structure of place names in different languages (see Section 1 for discussion) strongly suggests that the general approach proposed in this paper could be fruitfully applied to place names in other languages. In the long run, combining such studies with morpho-phonological analyses of other types of names (person names, street names, lake names, etc.) in different languages / language families could help to establish a typology of the synchronic structure of names that incorporates a fuller set of synchronic evidence than most previous studies have.

Abstracting away from the details of my approach, I hope to have demonstrated that many place names show predictable patterns of derivation that so far have been largely ignored but should be accounted for in a theory of grammar.

Acknowledgments I would like to thank Hans Bennis, Ricardo Bermúdez-Otero, Andrew Nevins, Marc van Oostendorp, and three anonymous reviewers for valuable discussions and suggestions. All remaining errors are mine.

Open Access This article is distributed under the terms of the Creative Commons Attribution 4.0 International License (http://creativecommons.org/licenses/by/4.0/), which permits unrestricted use, distribution, and reproduction in any medium, provided you give appropriate credit to the original author(s) and the source, provide a link to the Creative Commons license, and indicate if changes were made. 


\section{References}

Aikhenvald, Alexandra Y. 2000. Classifiers: a typology of noun categorization devices. Oxford: Oxford University Press.

Anderson, John M. 2004. On the grammatical status of names. Language 80: 435-474.

Anderson, John M. 2007. The grammar of names. Oxford: Oxford University Press.

Aronoff, Mark. 1976. Word formation in generative grammar. Cambridge, MA: MIT Press.

Bach, Adolf. 1953. Die deutschen Ortsnamen. Teil 1: Einleitung, Zur Laut-und Formenlehre, zur Satzfügung, Wortbildung und-bedeutung der deutschen Ortsnamen. Heidelberg: Carl Winter.

Backhouse, Anthony E. 1996. Proper names in Japanese: What the learner needs to know. In The fourth international symposium on language and linguistics, 1217-1239. Thailand: Institute for Language and Culture for Rural Development, Mahidol University.

Backhuys, Kees-Jan. 1989. Adjectival compounds in Dutch. In Linguistics in the Netherlands 1989, eds. Hans J. Bennis, and Ans van Kemenade, 1-10. Dordrecht: Foris.

Bennis, Hans J. 1993. Morfologie bestaat niet? Over de verhouding tussen zinsbouw en woordvorming. TABU 23: 15-28.

Bermúdez-Otero, Ricardo. 2012. The architecture of grammar and the division of labour in exponence. In The morphology and phonology of exponence, ed. Jochen Trommer, 8-83. Oxford: Oxford University Press.

Booij, Geert E. 1977. Dutch morphology. A study of word formation in generative grammar. Dordrecht: Foris.

Booij, Geert E. 1995. The phonology of Dutch. Oxford: Oxford University Press.

Booij, Geert E. 1999. The role of the prosodic word in phonotactic generalizations. Amsterdam Studies in the Theory and History of Linguistic Science 4: 47-72.

Booij, Geert E. 2007. The grammar of words. Oxford: Oxford University Press.

Booij, Geert E. 2010. Construction morphology. Oxford: Oxford University Press.

Botma, Bert. 2004. Phonological aspects of nasality: an element-based dependency approach. $\mathrm{PhD}$ dissertation, University of Amsterdam.

Bühnen, Stephan. 1992. Place names as an historical source: an introduction with examples from Southern Senegambia and Germany. History in Africa 19: 45-101.

Clahsen, Harald, and Kathleen Neubauer. 2010. Morphology, frequency, and the processing of derived words in native and non-native speakers. Lingua 120(11): 2627-37.

Dalberg, Vibeke. 2008. Name and place. Ten essays on the dynamics of place-names. Copenhagen: Department of Scandinavian Research.

De Coninck, Robrecht H.B. 1970. Groot uitspraakwoordenboek van de Nederlandse taal. Antwerpen: De Nederlandsche Boekhandel.

Endzelytè, Renata. 2004. Šiaurès vidurio Lietuvos vietovardžiai su priesaga -išk-. Acta Linguistica Lithuanica L: 1-10.

Ernestus, Mirjam, and Anneke Neijt. 2008. Word length and the location of primary word stress in Dutch, German, and English. Linguistics 46: 507-540.

Gerdts, Donna B. 2003. The morphosyntax of Halkomelem lexical suffixes. International Journal of American Linguistics 69: 345-356.

Gussenhoven, Carlos. 1984. On the grammar and semantics of sentence accents. Dordrecht: Foris.

Gussenhoven, Carlos. 2009. Vowel duration, syllable quantity, and stress in Dutch. In The nature of the word. Essays in honor of Paul Kiparsky, eds. Kristin Hanson, and Sharon Inkelas, 181-198. Cambridge, MA: MIT Press.

Halle, Morris. 1973. Prolegomena to a theory of word-formation. Linguistic Inquiry 4: 451-464.

Harvey, Mark. 1999. Place names and land-language associations in the western top end. Australian Journal of Linguistics 19(2): 161-195.

Heemskerk, Josée, and Wim Zonneveld. 2000. Uitspraakwoordenboek. Het Spectrum: Utrecht.

Hermans, Ben, and W. Leo Wetzels. 2012. Productive and unproductive stress patterns in Brazilian Portuguese. Revista Letras \& Letras 28(1): 77-114.

Jackendoff, Ray. 1997. The architecture of the language faculty. Cambridge, MA: MIT Press.

Jackendoff, Ray. 2002. Foundations of language: brain, meaning, grammar, evolution. Oxford: Oxford University Press. 
Kager, René. 1989. A metrical theory of stress and destressing in English and Dutch. Dordrecht: Foris.

Kager, René, and Wim Zonneveld. 1986. Schwa, syllables, and extrametricality in Dutch. The Linguistic Review 5(3): 197-221.

Kahn, Daniel. 1976. Syllable-based generalizations in English phonology. Bloomington: Indiana University Linguistics Club.

Kaufmann, Henning. 1977. Bildungsweise und Betonung der deutschen Ortsnamen. München: Fink.

Kaye, Jonathan. 1995. Derivations and interfaces. In Frontiers of phonology: Atoms, structures, derivations, eds. Jacques Durand, and Francis Katamba, 289-332. London: Longman.

Kinkade, M. Dale. 1963. Phonology and morphology of upper Chehalis: II. International Journal of American Linguistics 29(4): 345-356.

Kiparsky, Paul. 1982. From cyclic phonology to lexical phonology. In The structure of phonological representations (I), eds. Harry van der Hulst, and Norval Smith, 131-175. Dordrecht: Faris.

Köpke, Klaus-Michael, and David A. Zubin. 2005. Nominalphrasen ohne lexikalischen Kopf - Zur Bedeutung des Genus für die Organisation des mentalen Lexikons am Beispiel der Autobezeichnungen im Deutschen. Zeitschrift für Sprachwissenschaft 24: 93-122.

Kripke, Saul A. 1980. Naming and necessity. Cambridge, MA: Harvard University Press.

Langeweg, Simone. 1988. The stress system of Dutch. PhD Dissertation, Leiden University.

Leonard, Janet. 2007. A preliminary account of stress in SENĆOTEN (Saanich/North Straits Salish). Northwest Journal of Linguistics 1(4): 1-59.

Lieber, Rochelle. 1992. Deconstructing morphology: word formation in syntactic theory. Chicago: University of Chicago Press.

Longobardi, Giuseppe. 1994. Reference and proper names: a theory of n-movement. Linguistic Inquiry 25(4): 609-665.

Longobardi, Giuseppe. 2005. Toward a unified grammar of reference. Zeitschrift für Sprachwissenschaft 24(1): 5-44.

Mill, John Stuart. 1843. A system of logic, ratiocinative and inductive: being a connected view of the principles of evidence and the methods of scientific investigation. London: J.W. Parker.

Mojapelo, Mampaka L. 2009. Morphology and semantics of proper names in Northern Sotho. South African Journal of African Languages 29(2): 185-194.

Nouveau, Dominique. 1994. Language acquisition, metrical theory, and optimality. A study of Dutch word stress. PhD dissertation, Utrecht University.

Nübling, Damaris, Fabian Fahlbusch, and Rita Heuser. 2012. Namen. Eine Einführung in die Onomastik. Tübingen: Narr.

Oja, Vilja, and Marja Kallasmaa. 2013. Lexical relations in dialects and place names: Landscape terms. Euralex archive. http://www.euralex.org/elx_proceedings/Euralex2012/pp910-916\%200ja $\% 20$ and\%20Kallasmaa.pdf. Accessed 26 March 2013.

Packard, Jerome. 1998. New approaches to Chinese word formation. Berlin: de Gruyter.

Päll, Peeter. 2012. Observations on the geographical distribution of toponymic endings in Estonia. Esuka - Jeful 3(1): 155-172.

Phillips, Olena. 2010. Russian and Ukrainian adjectives referring to place names: A contrastive analysis. M.A. thesis, University of Arizona.

Prasithrathsint, Amara. 2007. Principles of Thai place-name formation: a reflection of natural and cultural heritage. International Journal of the Sociology of Language 186: 59-73.

Rohlfs, Gerhard. 1982. Streifzüge durch die italienische Toponomastik. In Substrate und Superstrate in den romanischen Sprachen, ed. Reinhold Kontzi, 451-481. Darmstadt: Wissenschaftliche Buchgesellschaft.

Sanders, Ewoud. 2003. Van Nergenshuizen tot Absurdistan. Verzonnen plaatsnamen in het Nederlands. Amsterdam: Prometheus / NRC Handelsblad.

Schrijnen, J. 1916. De klemtoon in de Nederlandse plaats- en straatnamen. De Nieuwe Taalgids 10: 142144.

Siegel, Dorothy C. 1974. Topics in English morphology. PhD dissertation, MIT.

Sproat, Richard, and Shih Chilin. 1996. A corpus-based analysis of Mandarin nominal root compounds. Journal of East Asian Linguistics 5(1): 49-71.

Stonham, John T. 1994. Combinatorial morphology. Amsterdam: John Benjamins.

Thompson, M. Terry. 1974. Harman Haeberlin's distribution of the Salish substantival [lexical] suffixes. Anthropological Linguistics 16: 219-350. 
Trommelen, Mieke, and Wim Zonneveld. 1986. Dutch morphology: evidence for the right-hand head rule. Linguistic Inquiry 17: 147-169.

Trommelen, Mieke, and Wim Zonneveld. 1989. Klemtoon en metrische fonologie. Muiderberg: Coutinho. van Berkel, Gerald, and Kees Samplonius. 2006. Nederlandse plaatsnamen. Herkomst en historie. Utrecht: Het Spectrum.

van der Hulst, Harry. 1984. Syllable structure and stress in Dutch. Dordrecht: Fortis.

van der Hulst, Harry. 2008. The Dutch diminutive. Lingua 118(9): 1288-1306.

van der Hulst, Harry. 2010. A note on recursion in phonology. In Recursion and human language, ed. Harry van der Hulst, 301-342. Berlin: Mouton de Gruyter.

van Langendonck, Willy. 1998. A typological approach to place name-categories. Proceedings of the XIXth International Congress of Onomastic Science. Scope, Perspectives and Methods of Onomastics (Aberdeen 1996), 342-348. Aberdeen: University of Aberdeen.

van Langendonck, Willy. 2007. Theory and typology of proper names. Berlin: Mouton de Gruyter.

van Lessen, Jacoba H. 1928. Samengestelde naamwoorden in het Nederlandsch. Groningen/Den Haag.

van Oostendorp, Marc. 1995. Vowel quality and syllable projection. PhD Dissertation, Tilburg University. van Oostendorp, Marc. 1997. Lexicale variatie in de optimaliteitstheorie. Nederlandse Taalkunde 1997: $13-145$.

van Oostendorp, Marc. 2000. Phonological projection: A theory of feature content and prosodic structure. Berlin: Mouton de Gruyter.

van Oostendorp, Marc. 2006. A Theory of morphosyntactic colours. http://egg.auf.net/06/docs/Hdt \%20Oostendorp\%20coulours.pdf. Accessed 12 March 2014.

van Oostendorp, Marc. 2012. Quantity and the three-syllable window in Dutch word stress. Language and Linguistics Compass 6(6): 343-358.

Van den Toorn, Maarten. 1980. Accentdifferentiatie bij eigennamen. Gramma 4: 153.

van der Torre, Erik. 2003. Dutch sonorants: The role of place of articulation in phonotactics. $\mathrm{PhD}$ dissertation, Leiden University.

Vidal, Denis, and Narayani Gupta. 1999. Urban vocabulary in Northern India. Management of Social Transformations (MOST) Programme, working paper Nr. 4.

Visch, Ellis. 1989. The rhythm rule in English and Dutch. PhD dissertation, Utrecht University.

Watts, Victor, and John Insley (Eds.) 2004. The Cambridge dictionary of English place-names: Based on the collections of the English Place-Name Society. Cambridge: Cambridge University Press.

Zonneveld, Wim. 1993. Schwa, superheavies, stress and syllables in Dutch. The Linguistic Review 10: 61110.

Zwart, Jan-Wouter. 2003. What's in a name? Syntactic and asyntactic accentuation in Dutch. In Grammatik i focus/Grammar in focus: Festschrift for Christer Platzack, eds. Lars-Olof Delsing, Cecilia Falk, Gunlög Josefsson, and Halldr A. Sigurðsson, 395-401. Lund: Wallin and Dalholm. 